\title{
CONCEPÇÕES SOBRE OS SINAIS DE PONTUAÇÃO POR ALUNOS DO ENSINO FUNDAMENTAL - ANOS INICIAIS
}

\author{
Raimunda Francisca de Sousa ${ }^{1}$ \\ Anderson Silva ${ }^{2}$
}

Resumo: Esta pesquisa discute a respeito da concepção que alunos do Ensino Fundamental têm sobre pontuação. Justifica-se este estudo pela escassez de trabalhos que explorem a temática. Como embasamento teórico, nos ancoramos nas contribuições da Análise Dialógica do Discurso, elegendo o conceito de enunciado concreto como categoria de análise. Da perspectiva metodológica, foi apresentada uma pergunta de pesquisa aos alunos de um $3^{\circ}$ ano de uma escola pública paulista. Em nossas considerações, a visão que os educandos possuem a respeito desse conteúdo no primeiro contato de alfabetização é intrinsecamente ligado aquilo que os professores comentam por meio de atividades didáticas.

Palavras-chave: Sinais de pontuação; Concepções; Análise dialógica do discurso.

${ }^{1}$ Secretaria Municipal de Educação de São José dos Campos, Brasil. E-mail: francisca.desousa2009@hotmail.com.

2 Pontifícia Universidade Católica de São Paulo/ Programa de Pós-Graduados em Linguística Aplicada e Estudos da Linguagem (LAEL), Brasil. E-mail: andcs23@hotmail.com. 